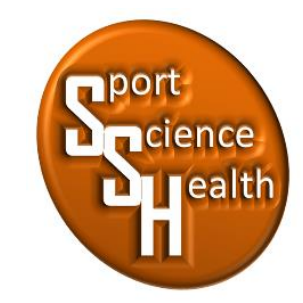

ISSN 2715-3886

\title{
Hubungan Antara Kekuatan Otot Lengan, Kekuatan Otot Tungkai dan Motivasi Berprestasi Dengan Prestasi Renang Gaya Bebas 50 Meter
}

\author{
Indra Kurniawan ${ }^{1 *}$, Mashuri Eko Winarno ${ }^{2}$ \\ 1,2Jurusan Pendidikan Jasmani, Kesehatan dan Rekreasi, Fakultas IImu Keolahragaan, \\ Universitas Negeri Malang, Jalan Semarang No 5, Malang, Jawa Timur, 65145, Indonesia \\ *Penulis koresponden: indrakurniawan3333nu@gmail.com, 082255155747
}

Artikel diterima: 15 Januari 2020; direvisi: 18 November 2020; disetujui: 23 November 2020

\begin{abstract}
The purpose of this study was to determine the relationship between arm muscle strength, leg muscle strength, and achievement motivation with the 50 meter freestyle swimming achievement. This study uses a correlational design. The subjects of this study were 21 athletes of the Artseidon Swimming Club. Data analysis included: normality test, homogeneity test, linearity test, hypothesis testing using product moment correlation, multiple correlation and multiple regression. The results of data analysis showed that there was a significant relationship between: (1) arm muscle strength and swimming performance, (2) leg muscle strength with swimming performance, (3) achievement motivation and swimming achievement, and (4) arm muscle strength, leg muscle strength. , and achievement motivation with swimming achievement.
\end{abstract}

Keyword: arm muscle strength, leg muscle strength, achievement motivation, swimming achievement

\begin{abstract}
Abstrak: Tujuan penelitian ini untuk mengetahui hubungan antara kekuatan otot lengan, kekuatan otot tungkai, dan motivasi berprestasi dengan prestasi renang gaya bebas 50 meter. Penelitian ini menggunakan rancangan korelasional. Subjek penelitian ini adalah 21 atlet Klub Artseidon Swimming. Analisis data diantaranya: uji normalitas, uji homogenitas, uji linieritas, uji hipotesis menggunakan korelasi product moment, korelasi berganda dan regresi berganda. Hasil analisis data menunjukkan ada hubungan yang signifikan antara: (1) kekuatan otot lengan dengan prestasi renang, (2) kekuatan otot tungkai dengan prestasi renang, (3) motivasi berprestasi dengan prestasi renang, dan (4) kekuatan otot lengan, kekuatan otot tungkai, dan motivasi berprestasi dengan prestasi renang.
\end{abstract}

Kata kunci: kekuatan otot lengan, kekuatan otot tungkai, motivasi berprestasi, prestasi renang

\section{PENDAHULUAN}

Renang adalah salah satu cabang olahraga aquatic yang dilakukan di dalam air. Terdapat empat gaya dalam olahraga renang yaitu gaya bebas (the crawl stroke), gaya dada (breast stroke), gaya kupu-kupu (butterfly stroke), dan gaya punggung (back stroke)(Koenig, Jarczok, Wasner, Hillecke, \& Thayer, 2014). Empat gaya renang tersebut juga termasuk dalam nomor-nomor dalam perlombaan renang. Selain gaya renang, yang termasuk dalam nomor-nomor perlombaan renang yaitu menurut jarak tempuh dan jenis kelamin. 
Renang adalah cabang olahraga yang sudah dikenal oleh seluruh kalangan masyarakat, baik dari anak-anak sampai orang dewasa. Renang merupakan salah satu cabang olahraga yang digemari oleh sebagian masyarakat di Indonesia, mulai dari kalangan anak-anak hingga orang dewasa baik di kota maupun di desa. Olahraga renang semakin berkembang, hal tersebut dapat dilihat dari adanya pembangunan prasarana olahraga renang maupun orang yang melakukan kegiatan olahraga renang. Dalam perkembangan olahraga khususnya cabang olahraga renang, banyak yang melakukan kegiatan renang dengan tujuan yang berbedabeda yaitu ada yang untuk meraih prestasi, melatih tubuh agar sehat, maupun sekedar mengisi waktu luang atau rekreasi.

Di Kota Malang Jawa Timur terdapat salah satu klub renang yaitu Artseidon Swimming. Klub Artseidon Swimming ini berdiri pada tahun 2016. Atlet yang masuk di Klub Artseidon Swimming ini dilatih untuk menjadi atlet berperstasi. Namun menjadi atlet yang berprestasi tidak semudah seperti yang dibayangkan, tentunya harus memiliki fisik yang baik dan motivasi berprestasi yang tinggi.

Bagi seorang atlet yang bertujuan ingin berprestasi dalam olahraga yang digelutinya maka harus memiliki faktor penunjang. Pencapaian prestasi dipengaruhi oleh tiga faktor diantaranya: (1) faktor fisik, (2) faktor teknik, dan (3) faktor psikologis (Fernandez-Fernandez, Sanz, Sarabia, \& Moya, 2017). Ketiga faktor tersebut saling berhubungan antara satu dengan yang lain.

Kondisi fisik menjadi faktor utama bagi atlet dalam pencapaian sebuah prestasi. Ada 10 komponen kondisi fisik dalam peningkatan prestasi seorang atlet antara lain: kekuatan, daya tahan, daya ledak, kecepatan, daya lentur, kelincahan, koordinasi, keseimbangan, ketepatan, dan reaksi (Rasyid, Setyakarnawijaya, dan Marani, 2017). Dalam olahraga renang diperlukan salah satu komponen kondisi fisik yaitu kekuatan yang berguna untuk bergerak (melaju ke depan) saat perenang berada di dalam air. Kekuatan merupakan kemampuan otot dalam tubuh yang digunakan untuk menahan beban. Anggota tubuh yang sangat berperan dalam olahraga renang yaitu lengan dan tungkai. Sehingga kekuatan otot lengan dan kekuatan otot tungkai sangat dibutuhkan saat berenang.

Kekuatan otot lengan sangat menentukan dalam mendapatkan hasil renang yang maksimal, khususnya pada renang gaya bebas. Kekuatan otot lengan berhubungan erat dengan kemampuan renang gaya bebas dengan menggunakan kekuatan gerak secara terus-menerus, karena saat melakukan gaya tersebut perenang berupaya memindahkan posisi tubuh dari start hingga ke finish (Jaryadi, 2013). Kekuatan otot tungkai sangat berperan penting dalam melakukan renang gaya bebas, karena kekuatan otot tungkai berguna sebagai pendorong ketika perenang melakukan renang gaya bebas agar memperoleh kecepatan yang maksimal (Rochmatullah, 2017). Berdasarkan penjelasan di atas diketahui bahwa kekuatan otot lengan dan kekuatan otot tungkai sangat berpengaruh terhadap renang gaya bebas, karena dapat berfungsi sebagai pendorong untuk memindahkan posisi tubuh perenang dari start sampai ke finish dengan kecepatan maksimal.

Faktor teknik juga berperan penting dalam pencapaian sebuah prestasi. Pada renang gaya bebas yang perlu diperhatikan yaitu gerakan kaki, gerakan lengan, dan koordinasi lengan, kaki serta pernapasan(Koenig et al., 2014). Diperlukan latihan teknik untuk menguasai gerakan-gerakan teknik tersebut. Sejalan dengan pernyataan tersebut, McFeeters (2013) menyatakan gerak-gerak dasar setiap teknik yang diperlukan dalam setiap cabang olahraga haruslah dilatih dan dikuasai secara sempurna serta dilakukan se-efisien mungkin.

Atlet yang memiliki keterampilan teknik yang sempurna dapat menunjang pencapaian prestasi yang setinggitingginya. Begitu juga sebaliknya jika seorang atlet tidak menguasai teknik dengan sempurna maka atlet tersebut akan mengalami hambatan dan kesulitan untuk mencapai prestasi yang tinggi. Keterampilan teknik meliputi teknik dasar, teknik menengah, dan teknik tinggi (Carden, Izard, Greeves, Lake, \& Myers, 2017).

Selain faktor fisik dan faktor teknik, faktor lain yang dapat mempengaruhi prestasi atlet yaitu faktor psikologis. Mulyana (2013) menyatakan motivasi berprestasi merupakan salah satu faktor psikologis yang termasuk menentukan prestasi perenang. Motivasi berprestasi adalah dorongan dalam diri seseorang untuk meraih sukses, yang cenderung menimbulkan perilaku untuk mempertahankan dan meningkatkan keberhasilan yang pernah dicapainya dengan berpedoman pada prestasi terbaik (Reiss, 2012).

Motivasi berprestasi juga berperan penting bagi atlet, karena motivasi berprestasi menentukan perilaku atlet saat berlatih maupun bertanding. Dalam berlatih atau bertanding dapat berhasil dengan baik jika seorang atlet memiliki motivasi berprestasi yang tinggi. Seperti halnya seorang atlet yang menjalankan program latihan sesuai dengan yang telah dibuat oleh pelatih. Bahkan atlet tersebut menambah latihannya di luar jam latihan 
yang sudah terjadwal dalam klub. Pada saat latihan maupun bertanding, atlet berusaha untuk melakukan yang terbaik. Sesuai dengan hasil penelitian Rahayu dan Mulyana (2015) bahwa ada hubungan yang positif antara goal-setting dan motivasi berprestasi dengan prestasi renang. Melalui suatu proses yang sistematis dilakukan secara berulang-ulang dapat membantu atlet dalam meningkatkan keterampilan, pembentukan kondisi fisik, pembentukan mental/psikologis, dan meningkatkan prestasinya semaksimal mungkin.

Berdasarakan latar belakang yang telah diuraikan di atas, perlu diteliti terkait faktor kondisi fisik dan faktor psikologis yang terjadi pada atlet Klub Artseidon Swimming, yaitu kekuatan otot lengan, kekuatan otot tungkai, dan motivasi berprestasi dengan prestasi renang gaya bebas 50 meter.

\section{Renang}

Renang merupakan suatu kegiatan yang sangat penting untuk dikuasai bagi setiap orang yang dapat berguna sebagai cara untuk bertahan hidup pada saat berada di dalam air. Renang adalah suatu cara untuk melewati permukaan air dengan menggerakkan anggota tubuh. Sedangkan Tierney (2011) berpendapat bahwa renang merupakan salah satu dari olahraga air yang mewajibkan atletnya untuk melakukan gerakan yang efektif dan efisien. Sejalan dengan pernyataan tersebut Crowley, Harrison, \& Lyons (2017) mengemukakan bahwa olahraga renang merupakan bentuk dari suatu aktivitas yang dilakukan di air untuk mengolah fisik yang dapat menyehatkan dan menyenangkan.

Berdasarkan pengertian yang dikemukakan oleh beberapa ahli tersebut, dapat disimpulkan bahwa olahraga renang merupakan salah satu olahraga air yang dilakukan dengan cara menggerakkan anggota tubuh secara efektif dan efisien. Selain memiliki fungsi sebagai kegiatan dalam mengisi waktu luang, menjaga kesehatan, menjaga keselamatan diri, berenang juga sebagai olahraga untuk meraih prestasi. Sejalan dengan pernyataan tersebut, (Eager, 2014) olahraga renang selain berfungsi sebagai olahraga rekreasi, dapat berfungsi sebagai sarana terapi bagi masalah-masalah kesehatan. Sukmawati (2015) berpendapat selain berguna untuk perlindungan diri, renang juga digunakan untuk meraih prestasi yang berguna bagi kehidupan individu tersebut.

Olahraga renang yang bertujuan untuk mencapai prestasi, maka dalam melakukan gerakan renang harus dilakukan dengan cara efektif dan efisien. Maksud dari gerakan efektif dan efisien yaitu bergerak dengan cara memperkecil atau mengurangi terjadinya hambatan pada saat berada di air. Dalam olahraga renang terdapat gaya renang yang diperlombakan yaitu gaya bebas, gaya punggung, gaya dada, dan gaya kupu-kupu (Robertson, Benardot, \& Mountjoy, 2014).

Setelah mengetahui berbagai macam-macam gaya renang. Menurut Neiva, Marques, Barbosa, Izquierdo, \& Marinho (2014)hal yang perlu diketahui agar perenang dapat berenang lebih cepat, harus melakukan salah satu dari hal-hal berikut: (1) mengurangi hambatan, (2) menambah dorongan, dan (3) mengkombinasikan dari keduanya.

Pada perlombaan renang terdiri dari nomor-nomor perlombaan menurut jarak tempuh, jenis kelamin, dan empat gaya renang. Adapun nomor-nomor renang putra dan putri yang diperlombakan dalam olimpiade renang gaya bebas sebagai berikut: 50 m, 100 m, 200 m, 400 m, 800 m (putri), dan 1500 m (putra) (Rasyid, Setyakarnawijaya, dan Marani, 2017).

\section{Renang Gaya Bebas}

Dalam cabang olahraga renang terdapat salah satu gaya renang yang paling cepat yaitu renang gaya bebas. Gaya bebas adalah gaya berenang dengan posisi badan telungkup, muka sebagian di permukaan air dana rah peandangan ke depan, bahu terangkat hampir sama dengan hidung, posisi pinggang sejajar bahu, kaki dan tangan lurus (Alkatan et al., 2016). Renang gaya bebas merupakan gaya renang yang tercepat dibandingkan dengan gaya yang lainnya. Renang gaya bebas adalah gaya renang yang dinilai paling cepat, efisien, dan sederhana (Mulyawati, Marijo, dan Indraswari, 2018).

Berdasarkan beberapa pendapat di atas dapat disimpulkan bahwa renang gaya bebas merupakan gaya renang paling cepat, sederhana, dan efisien dibandingkan dengan gaya renang lainnya, dapat dilakukan dengan cara posisi badan tengkurap, menggerakkan kaki naik dan turun, mengayunkan tangan ke depan secara bergantian, serta menolehkan kepala ke samping untuk bernafas. Terdapat empat komponen gerakan dalam renang gaya bebas yaitu, posisi badan, gerakan tangan, gerakan kaki, pengambilan nafas (Surahman, 2016). 


\section{Kekuatan Otot Lengan}

Kekuatan merupakan salah satu komponen kondisi fisik yang sangat penting bagi pencapaian prestasi, terutama dalam bidang olahraga. Kekuatan adalah kemampuan sekelompok otot yang bekerja untuk mengatasi beban pada saat melakukan aktivitas fisik (Sudarsono, 2015). Sejalan dengan pernyataan tersebut Schoenfeld (2012) menyatakan kekuatan otot adalah kemampuan otot untuk mengeluarkan tenaga secara maksimal dalam menahan beban. Kekuatan otot merupakan kemampuan otot untuk mengangkat beban dengan menggunakan tenaga secara maksimal. Berdasarkan beberapa pendapat tersebut dapat disimpulkan bahwa kekuatan adalah kemampuan sekelompok otot untuk menahan beban secara maksimal dalam sekali usaha.

Kekuatan otot lengan dapat menentukan kecepatan berenang, khususnya pada renang gaya bebas. Karena kemampuan gerak lengan yang cepat, efektif dan efisien dapat menghasilkan renang gaya bebas yang maksimal. Sehingga diperlukan gerakan lengan yang dilakukan dengan baik dan benar. Kekuatan otot lengan memiliki peran penting dalam berenang. Karena otot lengan adalah salah satu pendukung kekuatan dalam berenang (Rasyid, Setyakarnawijaya, dan Marani, 2017).

Untuk menghasilkan kecepatan renang gaya bebas yang maksimal maka kekuatan otot lengan harus kuat dalam melakukan renang gaya bebas agar tubuh terdorong dan melaju dengan cepat. Oleh karena itu perenang yang memiliki otot lengan yang kuat dapat dijadikan sebagai modal utama yang dapat menunjang kecepatan renang gaya bebas yang baik dan memberi peluang kepada perenang untuk meraih prestasi. Lengan adalah anggota gerak tubuh bagian atas yang tediri dari lengan atas dan lengan bawah. Lengan mempunyai tiga bagian otot yaitu: otot deltoid, otot bisep, dan otot trisep.

\section{Kekuatan Otot Tungkai}

Kekuatan adalah kemampuan otot untuk membangkitkan tegangan terhadap suatu tahanan. Kekuatan merupakan kemampuan otot untuk menerima beban secara maksimal. Kekuatan otot merupakan kemampuan sekelompok otot melakukan kontraksi secara maksimal untuk menahan beban. Berdasarkan beberapa pendapat tersebut dapat disimpulkan bahwa kekuatan otot tungkai adalah kemampuan otot bagian tungkai seseorang untuk menerima beban sewaktu melakukan aktivitas. Dalam olahraga renang khususnya pada renang gaya bebas, tungkai berfungsi sebagai penyeimbang atau stabilitator. Agar perenang tetap dalam keadaan streamline dan hambatan menjadi kecil. Oleh karena itu diperlukan kekuatan otot tungkai yang kuat agar perenang terdorong dan dapat melaju pada saat berada di air.

Pada saat melakukan renang gaya bebas diperlukan otot tungkai yang kuat untuk mendapatkan dorongan yang kuat pada tungkai. Kekuatan otot tungkai merupakan unsur dasar untuk memberikan dorongan terhadap gerakan supaya menjadi efektif dan efisien (Manshuralhudlori, 2019). Kekuatan yang dapat mendorong perenang saat berada di air salah satunya adalah kekuatan dorongan dari kaki (tungkai) (Lazar, Khanna, Chesler, \& Salciccioli, 2013). Sehingga gerakan kaki pada saat melakukan renang gaya bebas dapat membantu perenang untuk menghasilkan kecepatan renang yang baik.

Untuk menggerakkan otot tungkai, otot kaki terdiri dari: otot quadriceps extensor, gastrocnemius dan gluteus maximus, quadriceps extensor terdiri dari otot yaitu tensor fasia lata, sartorius, rectus femoris, vastus lateralis, vastus medialis, tibialis anterior, peroneus longus, soleus, dan maleoulus medialis.

\section{Motivasi Berprestasi}

Motivasi merupakan hal yang sangat penting bagi atlet karena dapat menunjang keberhasilan atlet dalam meraih prestasi. Motivasi berprestasi adalah dorongan dalam diri individu untuk berusaha meningkatkan kemampuan dengan berpacu pada standar keunggulan, baik keunggulan dirinya sendiri maupun orang lain (Rusli, 2017). Sejalan dengan hal tersebut (Dwija, 2008)(Dwija, 2008)(Dwija, 2008)(Dwija, 2008)(Dwija, 2008)(Dwija, 2008)(Dwija, 2008)(Dwija, 2008)(Dwija, 2008)(Dwija, 2008)(Dwija, 2008)(Dwija, 2008)(Dwija, 2008)(Dwija, 2008)(Dwija, 2008)(Dwija, 2008)(Dwija, 2008)(Dwija, 2008)(Dwija, 2008)(Dwija, 2008)dinyatakan bahwa motivasi berprestasi adalah suatu keadaan yang mendorong seseorang untuk melakukan usaha demi mencapai tujuannya sebaik mungkin didasari dengan standar keunggulan (Pelletier et al., 2016; Stoyanov, 2017). Purwanto (2019) juga berpendapat bahwa motivasi berprestasi merupakan daya penggerak dalam diri individu yang menimbulkan suatu usaha untuk mencapai tujuan dengan sebaik-baiknya.

Berdasarkan beberapa pendapat di atas dapat disimpulkan bahwa motivasi berprestasi merupakan dorongan yang ada dalam diri seseorang untuk mencapai tujuan secara maksimal, dengan cara mempertahankan dan 
meningkatkan suatu keberhasilan dengan berpedoman pada prestasi terbaik dirinya maupun orang lain. Seseorang yang memiliki motivasi berprestasi akan melakukan sebuah kegiatan lebih bersemangat, lebih baik, lebih cepat, lebih efisien, dan bertanggungjawab (Firmansyah, 2011). Artinya perenang akan lebih bersemangat, lebih baik, lebih cepat, lebih efisien, dan bertanggungjawab dalam melakukan renang gaya bebas.

Atlet dengan motivasi berprestasi yang tinggi akan menjalankan program latihan dengan kemauan yang tinggi dan bersungguh-sungguh. Dalam melakukan renang gaya bebas perenang akan melakukannya sebaik mungkin demi mendapatkan hasil yang maksimal. Motivasi berprestasi memberikan peluang kepada atlet demi mencapai sesuatu dengan sempurna melalui latihan secara maksimal dan dapat meningkatkan kebugaran pada tingkatan tertinggi (Riswanto, 2017). Chevallier, Kohls, Troiani, Brodkin, \& Schultz (2012) menyatakan bahwa motivasi berprestasi atlet dapat diidentifikasi melalui indikator: (1) memiliki kemauan keras dan pantang menyerah dalam berlatih, (2) memiliki harapan untuk sukses, (3) bertanggung jawab terhadap keberhasilan dalam berlatih dan selalu beorientasi ke depan dengan mewujudkannya dalam bentuk perilaku.

Membahas tentang motivasi, Lai (2011) membedakan motivasi menjadi 2 (dua) macam, yaitu motivasi intrinsik dan motivasi ekstrinsik. Guay, Vallerand, \& Blanchard (2000) berpendapat bahwa motivasi intrinsik merupakan dorongan yang tidak dirangsang dari luar diri individu. Artinya di dalam diri seseorang sudah terdapat dorongan tanpa adanya pengaruh dari luar atau orang lain. Sedangkan Deterding (2012) menyatakan motivasi ekstrinsik adalah munculnya dorongan dikarenakan ada pengaruh dari luar. Maksud dari pernyataan tersebut ialah motivasi ekstrinsik merupakan sebuah dorongan yang muncul disebabkan oleh adanya pengaruh berasal dari luar diri.

\section{Hubungan Kekuatan Otot Lengan Dengan Prestasi Renang Gaya Bebas 50 Meter}

Kekuatan sangat diperlukan untuk meraih sebuah prestasi dalam bidang olahraga renang, terutama dalam renang gaya bebas. Peningkatan kekuatan dapat dilakukan dengan melakukan latihan-latihan tertentu. Kekuatan otot lengan berarti sebagai kemampuan sekelompok otot bagian lengan yang digunakan untuk melakukan suatu gerak atau menahan beban.

Gerakan lengan pada renang gaya bebas merupakan bergerak mendayung yaitu dilakukan dengan cara menarik dan mendorong. Kekuatan otot lengan berperan untuk menahan atau melawan hambatan yang dihasilkan oleh air yang harus didesak maju (Maass, Krüger, Herminghaus, \& Bahr, 2016). Dibutuhkan kekuatan pada lengan untuk melakukan gerakan tersebut. Karena menggerakkan lengan di air lebih berat dibandingkan pada saat berada di luar air. Hal tersebut disebabkan oleh massa air yang lebih besar dibandingkan udara (Rasyid, Setyakarnawijaya, dan Marani, 2017). Dengan demikian diperlukan kekuatan otot lengan yang kuat untuk memperoleh hasil yang maksimal.

\section{Hubungan Kekuatan Otot Tungkai Dengan Prestasi Renang Gaya Bebas 50 Meter}

Dalam renang gaya bebas, sangat dibutuhkan kekuatan pada kaki atau tungkai. Karena tungkai pada saat melakukan renang gaya bebas bergerak naik turun. Gerakan naik turun pada tungkai dilakukan secara terus menerus. Sehingga diperlukan kekuatan otot tungkai dalam melakukan gerakan naik turun pada tungkai selama berenang gaya bebas.

Kekuatan otot tungkai berperan penting dalam renang gaya bebas, karena sebagai pendorong agar perenang dapat melaju ke depan. Dengan demikian, kelompok otot tungkai merupakan faktor pendukung utama untuk bergerak berada di air (Rasyid, Setyakarnawijaya, dan Marani, 2017).

\section{Hubungan Motivasi Berprestasi Dengan Prestasi Renang Gaya Bebas 50 Meter}

Motivasi berprestasi atlet renang berhubungan dengan tingkah laku dan perasaannya yaitu terkait dengan selalu berusaha keras dan pantang menyerah dalam berlatih, sesuai dengan tujuannya yaitu untuk mencapai prestasi renang gaya bebas melalui suatu persaingan baik diri sendiri maupun atlet renang lainnya. Perenang yang memiliki motivasi berprestasi yang tinggi, pada saat berlatih atlet tersebut akan selalu berusaha sebaik dan semaksimal mungkin dalam melakukan renang gaya bebas. Atlet yang mempunyai motivasi berprestasi tinggi, dalam berlatih atlet menampakkan minat yang besar dan penuh perhatian terhadap tugas berlatih (Buckley \& Doyle, 2016).

Atlet dengan motivasi berprestasi tinggi akan selalu melakukan yang terbaik dalam menjalankan tugas latihannya. Karena dengan memperoleh keberhasilan dalam berlatih dapat menimbulkan rasa bangga dan 
senang pada diri atlet. Atlet akan selalu berusaha dan terus berlatih apabila yang diperoleh belum maksimum. Dengan demikian diduga ada hubungan yang positif antara motivasi berprestasi dengan renang gaya bebas 50 meter.

\section{METODE}

Penelitian ini menggunakan jenis rancangan penelitian korelasional. Rancangan penelitian korelasional bertujuan untuk mengungkapkan hubungan antar variabel. Penelitian yang dilakukan adalah penelitian deskriptif, karena penelitian deskriptif bertujuan untuk mendeskripsikan atau memberikan gambaran yang jelas tentang apa yang diteliti dan menggunakan pendekatan kuantitatif yang berarti data yang dikumpulkan berupa angka. Penelitian ini berupaya untuk mengungkap hubungan kekuatan otot lengan, kekuatan otot tungkai, dan motivasi berprestasi dengan prestasi renang gaya bebas 50 meter pada atlet Klub Artseidon Swimming Kota Malang. Subjek dalam penelitian ini adalah atlet Klub Artseidon Swimming Kota Malang usia 8-11 tahun berjumlah 21 atlet.

Penelitian ini dilaksanakan di Kolam Renang Permata Jingga dan Kolam Renang Tirta Marabunta Kel. Kesatrian, Kec. Blimbing Kota Malang, Jawa Timur. Penelitian ini akan dilaksanakan pada minggu kedua bulan November 2019 pada pukul 15.30 - selesai dan pukul 08.00 - selesai.

Instrumen yang digunakan dalam penelitian ini yaitu; Tes pull and push dynamometer merupakan tes yang digunakan sesuai dengan tujuannya yaitu untuk mengukur kekuatan otot lengan. Alat yang digunakan dalam tes ini adalah pull and push dynamometer. Tes ini dilakukan dengan cara tester berdiri, memegang alat dengan kedua tangan di depan dada, lalu lakukan gerakan menarik dan mendorong pada alat dynamometer sekuatkuatnya dengan kedua tangan (Imansyah, 2012). Tes dilakukan dua kali, diambil yang terbaik. Hasil dari tes ini dinyatakan dalam satuan kilogram $(\mathrm{kg})$.

Tes leg dynamometer merupakan tes yang digunakan untuk mengukur kekuatan otot tungkai. Alat yang digunakan adalah leg dynamometer. Tes ini dilakukan dengan cara sebagai berikut; berdiri di atas papan dynamometer, kaki dibuka selebar $\pm 15 \mathrm{~cm}$, kedua tangan berpegangan pada pegangan dynamometer, kedua lutut bengkok dan punggung tegak, tester berusaha meluruskan kedua lutut semaksimal mungkin (Rochmatullah, 2017). Hasil yang diperoleh adalah angka yang ditunjukkan jarum pada saat meluruskan lutut.

Angket yang digunakan dalam penelitian ini adalah angket tertutup, dimana jawabannya sudah disediakan. Responden hanya memilih jawaban yang ada, dengan menggunakan skala likert sebagai berikut: 4, 3, 2, 1 untuk pernyataan positif dan 1, 2, 3, 4 untuk pernyataan yang bersifat negatif (Jamshed, 2014).

Tes kemampuan renang gaya bebas dengan jarak 50 meter merupakan tes yang digunakan untuk mengukur prestasi renang atlet Klub Artseidon Swimming. Pencatatan hasil yaitu perolehan waktu yang ditempuh perenang dari start sampai finish (Santoso, 2016). Pengumpulan data dalam penelitian ini menggunakan tes pull and push dynamometer, tes leg dynamometer, kuesioner atau angket dan tes renang gaya bebas jarak 50 meter. Analisis data dalam penelitian ini menggunakan jenis teknik analisis data korelasional. Analisis statistik yang digunakan yaitu korelasi product moment dan korelasi berganda (Adi \& Fathoni, 2020). Uji persyaratan dalam penelitian ini menggunakan uji normalitas, uji homogentias, dan uji linieritas (Tight, Symonds, \& Symonds, 2016).

\section{HASIL}

Penelitian ini merupakan penelitian korelasional yang bertujuan untuk mengetahui hubungan antara kekuatan otot lengan, kekuatan otot tungkai, dan motivasi berprestasi dengan prestasi renang gaya bebas 50 meter. Dari beberapa tes diperoleh sebuah data diantaranya; data tes kekuatan otot lengan berupa satuan kilogram $(\mathrm{kg})$, data tes kekuatan otot tungkai berupa satuan kilogram $(\mathrm{kg})$, data kuesioner berupa skor, dan data tes renang berupa satuan waktu (detik). Dalam melakukan analisis data, peneliti menggunakan SPSS. 
Tabel 1. Jumlah, Mean dan Standar Deviasi Masing-Masing Variabel $\mathrm{N}=21$

\begin{tabular}{lccc}
\hline \multicolumn{1}{c}{ Variabel } & Jumlah & Mean & Std. Deviasi \\
\hline Kekuatan Otot Lengan & 374 & 17,81 & 2,542 \\
Kekuatan Otot Tungkai & 872,5 & 41,55 & 6,620 \\
Motivasi Berprestasi & 1051 & 50,05 & 3,528 \\
Prestasi Renang & 1010,4 & 48,11 & 7,506 \\
\hline
\end{tabular}

Berdasarkan tabel 1. diperoleh jumlah, mean dan standar deviasi dari masing-masing variabel. Karena data dalam penelitian ini memiliki satuan yang berbeda, maka perlu distandarisasi menjadi T-skor.

\section{Uji Persyaratan Analisis}

Uji Normalitas

Uji normalitas dilakukan untuk mengetahui normal atau tidaknya suatu data. Untuk mengetahui normalitasnya, peneliti menggunakan uji liliefors. Berikut adalah hasil pengujian normalitas data.

Tabel 2. Hasil Uji Normalitas

\begin{tabular}{|c|c|c|c|}
\hline Variabel & Lnitung & Ltabel & Keterangan \\
\hline Kekuatan Otot Lengan & 0,089 & 0,190 & $L_{\text {hit }}<L_{\text {tab }}($ Normal $)$ \\
\hline Kekuatan Otot Tungkai & 0,153 & 0,190 & $L_{\text {hit }}<L_{\text {tab }}($ Normal) \\
\hline Motivasi Berprestasi & 0,188 & 0,190 & $L_{\text {hit }}<L_{\text {tab }}$ (Normal) \\
\hline Prestasi Renang & 0,117 & 0,190 & $\mathrm{~L}_{\text {hit }}<\mathrm{L}_{\mathrm{tab}}($ Normal $)$ \\
\hline
\end{tabular}

Tabel 2. menunjukkan bahwa data tiga variabel bebas dan satu variabel terikat berdistribusi normal.

\section{Uji Homogenitas}

Uji homogenitas merupakan pengujian mengenai sama tidaknya variansi-variansi dua buah distribusi atau lebih. Uji homogenitas dilakukan untuk mengetahui apakah data dalam variabel $X_{1}, X_{2}, X_{3}$, dan $Y$ bersifat homogen atau tidak.

Tabel 3. Hasil Uji Homogenitas

\begin{tabular}{lccc}
\hline \multicolumn{1}{c}{ Variabel } & Sig. & $\alpha$ & Keterangan \\
\hline Kekuatan Otot Lengan & 0,976 & 0,05 & Sig $>0,05$ (Homogen) \\
Kekuatan Otot Tungkai & & & \\
Motivasi Berprestasi & & & \\
Prestasi Renang & & & \\
\hline
\end{tabular}

Tabel 3. menunjukkan bahwa varian data tiga variabel bebas dan satu variabel terikat adalah homogen.

\section{Uji Linieritas}

Uji linieritas bertujuan untuk mengetahui apakah dua variabel mempunyai hubungan yang linier atau tidak secara signifikan.

Tabel 4. Hasil Uji Linieritas

\begin{tabular}{lccc}
\hline \multicolumn{1}{c}{ Variabel } & Sig & $\alpha$ & Keterangan \\
\hline Kekuatan Otot Lengan & 0,000 & 0,05 & Sig $<0,05$ (Linier) \\
Kekuatan Otot Tungkai & 0,000 & 0,05 & Sig $<0,05$ (Linier) \\
Motivasi Berprestasi & 0,000 & 0,05 & Sig $<0,05$ (Linier) \\
\hline
\end{tabular}


Tabel 4. menunjukkan bahwa hubungan masing-masing variabel bebas dengan variabel terikat bersifat linier.

\section{Uji Hipotesis}

Uji hipotesis adalah metode pengambilan keputusan didasarkan dari analisis data. Berdasarkan uji prasyarat analisis diketahui bahwa data berdistribusi normal, maka selanjutnya dapat dilakukan uji hipotesis. Uji hipotesis dilakukan dengan analisis korelasi product moment untuk korelasi antar variabel dan analisis korelasi berganda untuk tiga variabel bebas dengan satu variabel terikat. Kriteria penerimaan atau penolakan hipotesis statistik pada koefisien korelasi yaitu jika $\mathrm{r}_{\text {hitung }}>\mathrm{r}_{\text {tabel }}$ maka hipotesis nihil $\left(\mathrm{H}_{0}\right)$ ditolak dan hipotesis alternatif $\left(\mathrm{H}_{\mathrm{a}}\right)$ diterima. Namun jika $\mathrm{r}_{\mathrm{itung}}<\mathrm{r}_{\text {tabel }}$ maka hipotesis nihil $\left(\mathrm{H}_{0}\right)$ diterima dan hipotesis alternatif $\left(\mathrm{H}_{\mathrm{a}}\right)$ ditolak. Sehingga dapat dideskripsikan sebagai berikut: (1) Berdasarkan analisis data diperoleh hasil $r_{\text {hitung }} 0,870>r_{\text {tabel }}$ 0,433 pada taraf signifikansi $5 \%$, maka $\mathrm{H}_{0}$ ditolak dan $\mathrm{H}_{a}$ diterima, (2) Berdasarkan analisis data diperoleh hasil $r_{\text {hitung }} 0,851>\mathrm{r}_{\text {tabel }} 0,433$ pada taraf signifikansi $5 \%$, maka $\mathrm{H}_{0}$ ditolak dan $\mathrm{H}_{\mathrm{a}}$ diterima, (3) Berdasarkan analisis data diperoleh hasil $\mathrm{r}_{\text {hitung }} 0,724>\mathrm{r}_{\text {tabel }} 0,433$ pada taraf signifikansi $5 \%$, maka $\mathrm{H}_{0}$ ditolak dan $\mathrm{H}_{\mathrm{a}}$ diterima dan (4) Berdasarkan analisis data diperoleh hasil $R_{\text {hitung }} 0,886>R_{\text {tabel }} 0,413$ pada taraf signifikansi $5 \%$, maka $\mathrm{H}_{0}$ ditolak dan $\mathrm{H}_{\mathrm{a}}$ diterima.

\section{Korelasi Sederhana Antar Variabel}

Uji signifikansi nilai koefisien korelasi product moment merupakan uji yang digunakan untuk mengetahui apakah ada hubungan atau tidak antara variabel bebas yaitu kekuatan otot lengan $\left(X_{1}\right)$, kekuatan otot tungkai $\left(\mathrm{X}_{2}\right)$, dan motivasi berprestasi $\left(\mathrm{X}_{3}\right)$ dengan variabel terikat yaitu prestasi renang $(\mathrm{Y})$. Kriteria dinyatakan ada hubungan jika hasil $r_{\text {hitung }} X_{1} Y, X_{2} Y, X_{3} Y>r_{\text {tabel }}$ dengan taraf signifikansi $5 \%$, sebaliknya jika hasil $r_{\text {hitung }} X_{1} Y$, $\mathrm{X}_{2} \mathrm{Y}, \mathrm{X}_{3} \mathrm{Y}<\mathrm{r}$ tabel dinyatakan tidak ada hubungan dengan taraf signifikansi $5 \%$.

Tabel 5. Hasil Korelasi Product Moment

\begin{tabular}{lccc}
\hline \multicolumn{1}{c}{ Variabel } & rhitung & $r_{\text {tabel }}$ & Keterangan \\
\hline $\begin{array}{l}\text { Kekuatan Otot Lengan } \\
\text { dengan Prestasi Renang }\end{array}$ & 0,870 & 0,433 & $r_{\text {hit }}>r_{\text {tab }}$ (Ada hubungan) \\
$\begin{array}{l}\text { Kekuatan Otot Tungkai } \\
\text { dengan Prestasi Renang }\end{array}$ & 0.851 & 0,433 & $r_{\text {hit }}>r_{\text {tab }}$ (Ada hubungan) \\
$\begin{array}{l}\text { Motivasi Berprestasi } \\
\text { dengan Prestasi Renang }\end{array}$ & 0,724 & 0,433 & $r_{\text {hit }}>r_{\text {tab }}$ (Ada hubungan) \\
\hline
\end{tabular}

Tabel 5. di atas menunjukkan bahwa ada hubungan yang signifikan antara variabel bebas dengan variabel terikat yaitu; 1 ) kekuatan otot lengan $\left(X_{1}\right)$ dengan prestasi renang $(Y)$. 2) kekuatan otot tungkai $\left(X_{2}\right)$ dengan prestasi renang $(\mathrm{Y})$. 3) motivasi berprestasi $\left(\mathrm{X}_{3}\right)$ dengan prestasi renang $(\mathrm{Y})$.

\section{Korelasi Berganda}

Uji regresi berganda digunakan untuk mengetahui ada tidaknya hubungan secara bersama-sama antara kekuatan otot lengan $\left(\mathrm{X}_{1}\right)$, kekuatan otot tungkai $\left(\mathrm{X}_{2}\right)$, motivasi berprestasi $\left(\mathrm{X}_{3}\right)$ dengan prestasi renang $(\mathrm{Y})$. Setelah dilakukan analisis data, hasil yang diperoleh dapat dilihat pada Tabel 6.

Tabel 6. Hasil Analisis Regresi Berganda

\begin{tabular}{lcccc}
\hline \multicolumn{1}{c}{ Variabel } & $\begin{array}{c}\text { Koefisien } \\
\text { Regresi }\end{array}$ & Rhitung & R $_{\text {tabel }}$ & Keterangan \\
\hline Konstanta & 2,772 & & & \\
Kekuatan Otot Lengan & 0,367 & 0,886 & 0,413 & $R_{\text {hit }}>R_{\text {tab }}$ (Ada hubungan) \\
Kekuatan Otot Tungkai & 0,372 & & & \\
Motivasi Berprestasi & 0,205 & & & \\
\hline
\end{tabular}

Tabel 6. menunjukkan bahwa ada hubungan yang signifikan secara bersama-sama antara kekuatan otot lengan, kekuatan otot tungkai, dan motivasi berprestasi dengan prestasi renang gaya bebas 50 meter.

Persamaan regresi berganda dapat ditulis sebagai berikut: $\widehat{Y}=2,772+0,367 X_{1}+0,372 X_{2}+0,205 X_{3}$ 


\section{Sumbangan Efektif Dan Sumbanan Relatif}

Sumbangan efektif (SE) merupakan ukuran sumbangan variabel bebas terhadap variabel terikat dalam analisis regresi. Jumlah sumbangan efektif dari seluruh variabel bebas sama dengan jumlah $R$ square. Sedangkan sumbangan relatif (SR) merupakan ukuran besarnya sumbangan variabel bebas terhadap jumlah kuadrat regresi. Jumlah sumbangan relatif dari semua variabel bebas adalah $100 \%$ atau sama dengan 1 .

Tabel 7. Hasil Sumbangan Efektif dan Sumbangan Relatif

\begin{tabular}{lcc}
\hline \multicolumn{1}{c}{ Variabel } & SE \% & SR \% \\
\hline Kekuatan Otot Lengan & 31,93 & 40,7 \\
Kekuatan Otot Tungkai & 31,66 & 40,4 \\
Motivasi Berprestasi & 14,84 & 18,9 \\
\hline Total & 78,43 & 100 \\
\hline
\end{tabular}

Tabel 7. menunjukkan bahwa sumbangan efektif (SE) dan sumbangan relatif (SR) terbesar diberikan oleh variabel kekuatan otot lengan, kemudian diikuti oleh variabel kekuatan otot tungkai, dan variabel motivasi berprestasi.

\section{PEMBAHASAN}

\section{Hubungan Kekuatan Otot Lengan Dengan Prestasi Renang Gaya Bebas 50 Meter}

Pada uji hipotesis yang pertama yaitu ada hubungan antara kekuatan otot lengan dengan prestasi renang gaya bebas 50 meter. Hasil uji hipotesis menggunakan analisis korelasi product moment. Berdasarkan analisis korelasi diperoleh koefisien korelasi antara kekuatan otot lengan dengan prestasi renang gaya bebas 50 meter sebesar 0,870 . Keberartian koefisien korelasi dilakukan dengan cara membandingkan antara ritung dengan $r_{\text {tabel, }}$ pada taraf signifikansi $5 \%$ dengan $\mathrm{N}=21$ diperoleh $r_{\text {tabel }}$ sebesar 0,433 . Karena koefisien korelasi $r_{X 1 Y}=$ $0,870>r_{\text {tabel }}=0,433$, artinya koefisien korelasi tersebut signifikan.

Hasil penelitian ini menunjukkan bahwa kekuatan otot lengan merupakan salah satu faktor yang dapat mempengaruhi prestasi renang gaya bebas 50 meter. Hasil penelitian ini diperkuat dengan hasil penelitian sebelumnya yang dilakukan oleh Santoso (2016) menyatakan bahwa ada hubungan yang signifikan antara kekuatan otot lengan terhadap prestasi renang gaya bebas 50 meter pada siswa putra SMK PGRI 4 Kediri tahun 2015. Shaw, Boyd, Burke, \& Koivisto (2014) juga menyatakan bahwa ada hubungan yang signifikan antara kekuatan otot lengan dengan prestasi renang gaya bebas 25 meter. Serta Rasyid, Setyakarnawijaya, dan Marani (2017) mengatakan bahwa terdapat hubungan yang berarti antara kekuatan otot lengan dengan hasil renang gaya bebas 50 meter pada atlet Millennium Aquatic Swimming Club.

Kekuatan otot lengan merupakan kemampuan otot lengan untuk menahan beban secara maksimal sewaktu bekerja. Kekuatan otot lengan memiliki peranan penting dalam olahraga renang khususnya pada renang gaya bebas. Kadari (2018) agar dapat menghasilkan kecepatan renang gaya bebas, maka diperlukan otot lengan yang kuat saat melakukan renang gaya bebas agar tubuh dapat melaju dengan cepat. Lengan merupakan anggota gerak tubuh bagian atas yang berfungsi sebagai pendayung pada saat melakukan renang gaya bebas. Gerakan mendayung ini dilakukan secara terus-menerus dan bergantian antara lengan kanan dan kiri. Sehingga dibutuhkan kekuatan pada otot lengan untuk melakukan gerakan tersebut untuk menghasilkan tubuh dapat bergerak maju dari posisi start hingga finish secara maksimal.

Perenang yang memiliki otot lengan yang kuat bukan berarti mengesampingkan faktor pendukung yang lain untuk mencapai sebuah prestasi. Faktor pendukung lain yaitu faktor teknik, gerakan lengan pada saat renang gaya bebas harus dilakukan dengan baik dan benar untuk mendapatkan hasil yang masksimal. Ada empat langkah melakukan gerak lengan antara lain, menangkap, meraih, menarik, dan mendorong. Keempat langkah gerakan lengan tersebut harus dikuasai oleh perenang untuk mendapatkan hasil renang gaya bebas yang maksimal.

Kekuatan otot lengan atlet Artseidon Swimming ini termasuk dalam kategori rendah. Hal tersebut dikarenakan faktor usia atlet yang masih anak-anak. Faktor fisik yaitu kekuatan masih belum waktunya untuk berkembang, yang lebih dulu berkembang pada usia anak-anak adalah kelincahan. Pada masa ini ditandai dengan kelebihan gerak atau aktivitas gerak yang lincah. 
Berdasarkan penjelasan di atas maka kekuatan sangat penting yang berguna untuk meningkatkan kondisi fisik secara keseluruhan dan berperan penting dalam aktivitas olahraga. Sebagai penunjang untuk mendapatkan hasil yang maksimal maka diperlukan latihan untuk memperbaiki dan meningkatkan kualitas dalam melakukan aktivitas gerak. Apabila seorang atlet memiliki kekuatan otot lengan yang kuat akan dapat menunjang pencapaian prestasi renang yang maksimal. Sehingga ada hubungannya antara kekuatan otot lengan dengan prestasi renang gaya bebas 50 meter.

\section{Hubungan Kekuatan Otot Tungkai Dengan Prestasi Renang Gaya Bebas 50 Meter}

Pada uji hipotesis yang kedua yaitu ada hubungan antara kekuatan otot tungkai dengan prestasi renang gaya bebas 50 meter. Hasil uji hipotesis menggunakan analisis korelasi product moment. Berdasarkan analisis korelasi diperoleh koefisien korelasi antara kekuatan otot tungkai dengan prestasi renang gaya bebas 50 meter sebesar 0,851 . Keberartian koefisien korelasi dilakukan dengan cara membandingkan antara ritung dengan $r_{\text {tabel, }}$ pada taraf signifikansi $5 \%$ dengan $\mathrm{N}=21$ diperoleh $r_{\text {tabel }}$ sebesar 0,433 . Karena koefisien korelasi $r_{\times 2} Y=$ $0,851>$ rtabel $=0,433$, artinya koefisien korelasi tersebut signifikan.

Dari hasil penelitian ini diketahui bahwa kekuatan otot tungkai dapat mempengaruhi prestasi renang gaya bebas 50 meter. Hasil penelitian ini diperkuat dengan hasil penelitian sebelumnya yang dilakukan oleh Imansyah (2012) bahwa ada hubungan yang signifikan antara kekuatan otot tungkai dengan hasil kecepatan renang gaya bebas 50 meter pada atlet putri Club Bangka Swimming. Rochmatullah (2017) juga menyatakan bahwa terdapat hubungan antara kekuatan otot lengan dengan kecepatan renang gaya bebas 50 meter. Hasil penelitian Darsono (2019) menyatakan bahwa ada hubungan antara kekuatan otot tungkai dengan hasil renang gaya bebas 50 meter pada siswa kelas X SMK Pemuda Papar Kabupaten Kediri tahun ajaran 2018/2019.

Kekuatan otot tungkai merupakan kemampuan sekelompok otot pada tungkai untuk menahan beban secara maksimal selama melakukan aktivitas. Kekuatan otot tungkai juga memiliki peranan penting dalam renang gaya bebas. Karena kekuatan otot tungkai berfungsi sebagai pendorong tubuh pada saat melakukan renang gaya bebas. Gerakan tungkai pada renang gaya bebas dilakukan naik turun secara bergantian. Gerakan yang dihasilkan oleh tungkai dapat berfungsi sebagai penyeimbang agar perenang tetap berada pada posisi stream line dan memperoleh dorongan untuk melaju ke depan.

Pada renang gaya bebas salah satu usaha yang dilakukan untuk memperoleh dorongan ke depan yaitu berasal dari ayunan kaki/tungkai (Manshuralhudlori, 2019). Saat melakukan ayunan kaki diperlukan kekuatan otot tungkai karena selama melakukan renang gaya bebas, tungkai harus bergerak terus-menerus dan naik turun secara bergantian. Oleh karena itu gerakan yang dihasilkan oleh kekuatan otot tungkai dapat menunjang untuk mendapatkan hasil renang gaya bebas yang optimal. Berdasarkan uraian di atas diketahui bahwa ada hubungan antara kekuatan otot tungkai dengan prestasi renang gaya bebas 50 meter.

Selain kekuatan otot tungkai, ada faktor yang juga memiliki peranan penting dalam renang gaya bebas yaitu faktor teknik khususnya gerakan kaki. Pada saat melakukan renang gaya bebas, kaki digerakkan ke atas dan ke bawah secara maksimal dari pangkal paha. Prinsip yang harus diingat dan dilakukan yaitu gerakan kaki selalu dimulai dari pangkal paha. Sehingga gerakan tersebut dapat dilakukan secara efeketif dan efisien untuk memperoleh hasil yang maksimal.

Kekuatan otot tungkai atlet Artseidon Swimming ini juga termasuk dalam kategori rendah. Selain faktor usia yang masih anak-anak, faktor lain yang mempengaruhi yaitu otot dan lemak. Pada masa anak-anak, jaringan lemak berkembang lebih cepat daripada jaringan otot yang perkembangannya baru mulai melejit pada awal pubertas (Peyer, Zhang, \& Nelson, 2013). Sehingga pada masa ini bukan merupakan waktu yang tepat bagi kekuatan otot untuk berkembang.

\section{Hubungan Motivasi Berprestasi Dengan Prestasi Renang Gaya Bebas 50 Meter}

Pada uji hipotesis yang ketiga yaitu ada hubungan antara motivasi berprestasi dengan prestasi renang gaya bebas 50 meter. Hasil uji hipotesis menggunakan analisis korelasi product moment. Berdasarkan analisis korelasi diperoleh koefisien korelasi antara kekuatan otot lengan dengan prestasi renang gaya bebas 50 meter sebesar 0,724 . Keberartian koefisien korelasi dilakukan dengan cara membandingkan antara ritung $_{\text {dengan }}$ $r_{\text {tabel, }}$ pada taraf signifikansi $5 \%$ dengan $\mathrm{N}=21$ diperoleh $r_{\text {tabel }}$ sebesar 0,433 . Karena koefisien korelasi $r_{\times 3} Y=$ $0,724>r_{\text {tabel }}=0,433$, artinya koefisien korelasi tersebut signifikan. 
Dari hasil penelitian ini diketahui bahwa motivasi berprestasi dapat mempengaruhi prestasi renang gaya bebas 50 meter. Hasil penelitian ini diperkuat dengan hasil penelitian sebelumnya yang dilakukan oleh Mulyana (2013) menunjukkan bahwa ada hubungan antara motivasi berprestasi dengan prestasi renang gaya bebas. Hasil penelitian sejalan juga ditunjukkan oleh Rahayu dan Mulyana (2015) bahwa terdapat hubungan antara motivasi berprestasi dengan prestasi atlet renang.

Berdasarkan hasil penelitian ini dimana ada hubungan antara motivasi berprestasi dengan prestasi renang gaya bebas 50 meter. Temuan ini sejalan dengan teori bahwa motivasi berprestasi merupakan keinginan dalam diri seorang atlet untuk meningkatkan kemampuan maupun menyelesaikan tugasnya sebaik mungkin dengan berpatokan pada prestasi yang telah dicapai oleh dirinya maupun orang lain (Rusli, 2017). Motivasi berprestasi merupakan dorongan yang timbul pada diri seseorang untuk meraih kesuksesan, yang cenderung untuk mempertahankan dan meningkatkan sebuah keberhasilan dengan berpedoman baik pada prestasi diri sendiri maupun orang lain.

Seorang perenang yang memiliki motivasi berprestasi, cenderung akan melakukan sesuatu dengan sungguhsungguh, kerja keras, dan tidak mudah putus asa demi mewujudkan keinginannya. Sama halnya seperti perenang pada saat melakukan renang gaya bebas yang mempunyai keinginan dan berusaha untuk memperoleh catatan waktu renang sebaik-baiknya. Sehingga peluang untuk mencapai prestasi yang maksimal akan mudah untuk diperoleh.

\section{Hubungan Kekuatan Otot Lengan, Kekuatan Otot Tungkai dan Motivasi Berprestasi Dengan Prestasi Renang Gaya Bebas 50 Meter}

Pada uji hipotesis yang keempat yaitu ada hubungan antara kekuatan otot lengan, kekuatan otot tungkai, dan motivasi berprestasi dengan prestasi renang gaya bebas 50 meter. Hasil uji hipotesis menggunakan analisis korelasi berganda. Berdasarkan analisis korelasi diperoleh koefisien korelasi antara kekuatan otot lengan, kekuatan otot tungkai, dan motivasi berprestasi dengan prestasi renang gaya bebas 50 meter sebesar 0,886. Keberartian koefisien korelasi dilakukan dengan cara membandingkan antara $\mathrm{R}_{\text {hitung }}$ dengan $\mathrm{R}_{\text {tabel, }}$ pada taraf signifikansi $5 \%$ dengan $\mathrm{N}=21$ diperoleh $\mathrm{r}_{\text {tabel }}$ sebesar 0,413 . Karena koefisien korelasi $\mathrm{R}_{\mathrm{Y} . \mathrm{X} 1 \times 2 \times 3}=0,886>$ $R_{\text {tabel }}=0,413$, artinya koefisien korelasi tersebut signifikan.

Temuan yang terakhir berdasarkan hasil penelitian ini diperkuat dengan hasil penelitian sebelumnya yang dilakukan oleh Ferdiansyah (2017) menyatakan bahwa ada hubungan antara kekuata otot lengan dengan hasil renang gaya bebas pada siswa putra SMK Pelayaran Satria Bahari Bandar Lampung. Mulyana (2013) menunjukkan bahwa ada hubungan antara motivasi berprestasi dengan prestasi renang gaya bebas.

Faktor fisik menjadi faktor utama dalam pencapaian prestasi renang karena memiliki pengaruh yang besar. Dimana gerakan yang dihasilkan oleh anggota gerak tubuh yaitu lengan dan tungkai dapat memindahkan tubuh dari satu tempat ke tempat yang lain (start sampai ke finish). Untuk mendapatkan hasil renang gaya bebas yang optimal maka dibutuhkan sebuah kekuatan pada tubuh perenang. Anggota tubuh yaitu menyangkut kekuatan otot lengan dan kekuatan otot tungkai merupakan salah satu potensi yang baik untuk menghasilkan kecepatan dalam renang (Darsono, 2019). Oleh karena itu kekuatan otot lengan dan kekuatan otot tungkai menjadi salah satu faktor yang penting dalam prestasi renang untuk dapat mendorong tubuh melaju dengan cepat saat berada di air.

Selanjutnya yang memberikan pengaruh terhadap prestasi renang yaitu faktor psikologis. Faktor psikologis dalam diri atlet yaitu berupa motivasi berprestasi. Motivasi berprestasi ini berperan sebagai pendorong atlet dalam melakukan aktivitas fisik guna untuk mendapatkan hasil renang yang maksimal. Motivasi berprestasi memungkinkan setiap individu untuk memberikan usaha yang baik sehingga dapat menghasilkan sebuah prestasi yang baik juga (Rahayu dan Mulyana, 2015). Dengan demikian motivasi berprestasi dapat membantu atlet renang untuk menyelesaikan tugasnya sebaik mungkin.

Berdasarkan hasil penelitian antara kekuatan otot lengan, kekuatan otot tungkai, dan motivasi berprestasi mempunyai kontribusi yang berbeda terhadap prestasi renang gaya bebas 50 meter. Dimana sumbangan terbesar diberikan oleh kekuatan otot lengan, selanjutnya sumbangan dari kekuatan otot tungkai dan yang terakhir yaitu motivasi berprestasi. 


\section{KESIMPULAN}

Berdasarkan analisis data dan pembahasan hasil penelitian maka dapat disimpulkan bahwa: (1) Ada hubungan antara kekuatan otot lengan dengan prestasi renang gaya bebas 50 meter. (2) Ada hubungan antara kekuatan otot tungkai dengan prestasi renang gaya bebas 50 meter. (3) Ada hubungan antara motivasi berprestasi dengan prestasi renang gaya bebas 50 meter. Dan (4) Ada hubungan antara kekuatan otot lengan, kekuatan otot tungkai, dan motivasi berprestasi dengan prestasi renang gaya bebas 50 meter.

\section{DAFTAR PUSTAKA}

Adi, S., \& Fathoni, A. F. (2020). The effectiveness and efficiency of blended learning at sport schools in Indonesia. International Journal of Innovation, Creativity and Change.

Alkatan, M., Baker, J. R., Machin, D. R., Park, W., Akkari, A. S., Pasha, E. P., \& Tanaka, H. (2016). Improved function and reduced pain after swimming and cycling training in patients with osteoarthritis. Journal of Rheumatology. https://doi.org/10.3899/jrheum.151110

Buckley, P., \& Doyle, E. (2016). Gamification and student motivation. Interactive Learning Environments. https://doi.org/10.1080/10494820.2014.964263

Carden, P. P. J., Izard, R. M., Greeves, J. P., Lake, J. P., \& Myers, S. D. (2017). Force and acceleration characteristics of military foot drill: Implications for injury risk in recruits. BMJ Open Sport and Exercise Medicine. https://doi.org/10.1136/bmjsem-2015-000025

Chevallier, C., Kohls, G., Troiani, V., Brodkin, E. S., \& Schultz, R. T. (2012). The social motivation theory of autism. Trends in Cognitive Sciences. https://doi.org/10.1016/j.tics.2012.02.007

Crowley, E., Harrison, A. J., \& Lyons, M. (2017). The Impact of Resistance Training on Swimming Performance: A Systematic Review. Sports Medicine. https://doi.org/10.1007/s40279-017-0730-2

Darsono, S. (2019). Hubungan Antara Kekuatan Otot Lengan Dan Kekuatan Otot Tungkai Terhadap Prestasi Renang Gaya Bebas 50 Meter Bagi Siswa Kelas X SMK Pemuda Papar. Jurnal Pendidikan Jasmani, Kesehatan Dan Rekreasi, 5-10.

Deterding, S. (2012). Gamification: designing for motivation. Interactions. https://doi.org/10.1145/2212877.2212883

Dwija, I. W. (2008). Hubungan Antara Konsep Diri, Motivasi Berprestasi Dan Perhatian Orang Tua Dengan Hasil Belajar Sosiologi Pada Siswa Kelas li Sekolah Menengah Atas Unggulan Di Kota Amlapura. Jurnal Pendidikan Dan Pengajaran, (1), 628-649.

Eager, D. (2014). Swimming faster. Australasian Parks and Leisure.

Ferdiansyah. (2017). Hubungan Antara Kekuatan Otot Tungkai dan Kekuatan Otot Lengan Dengan Hasil Renang Gaya Bebas Pada Siswa Putra SMK Pelayaran Satria Bahari Bandar Lampung.

Fernandez-Fernandez, J., Sanz, D., Sarabia, J. M., \& Moya, M. (2017). The effects of sport-specific drills training or high-intensity interval training in young tennis players. International Journal of Sports Physiology and Performance. https://doi.org/10.1123/ijspp.2015-0684

Firmansyah, H. (2011). Hubungan Motivasi Berprestasi Siswa Dengan Hasil Belajar Pendidikan Jasmani. Jurnal Pendidikan Jasmani Indonesia, 6(1), 30-33.

Guay, F., Vallerand, R. J., \& Blanchard, C. (2000). On the assessment of situational intrinsic and extrinsic motivation: The Situational Motivation Scale (SIMS). Motivation and Emotion. https://doi.org/10.1023/A:1005614228250

Imansyah, F. (2012a). Hubungan Anara Kekuatan Otot Tungkai Dan Kekuatan Otot Lengan Terhadap Hasil Kecepatan Renang 50 Meter Gaya Bebas Pada Atlet Putri Club Bangka Swimming. 66, 37-39.

Imansyah, F. (2012b). Hubungan Anara Kekuatan Otot Tungkai Dan Kekuatan Otot Lengan Terhadap Hasil Kecepatan Renang 50 Meter Gaya Bebas Pada Atlet Putri Club Bangka Swimming. Jurnal IImu Keolahragaan, 66, 37-39. 
Jamshed, S. (2014). Qualitative research method-interviewing and observation. Journal of Basic and Clinical Pharmacy. https://doi.org/10.4103/0976-0105.141942

Jaryadi, N. (2013). Hubungan Kekuatan Otot Lengan dan Tungkai Dengan Prestasi Renang 25 Meter Gaya Bebas Pada Mahasiswa Penjaskes Angkatan 2012 Tahun Pelajaran 2012/2013. Jurnal Penjaskesrek.

Kadari, D. S. (2018). Kontribusi Kekuatan Lengan, Kekuatan Otot Perut, Dan Kekuatan Otot Tungkai Terhadap Kemampuan Renang 50 Meter Gaya Bebas Pada Mahasiswa FIK UNM. Journal Of Physical Education, Sport and Recreation, (1).

Koenig, J., Jarczok, M. N., Wasner, M., Hillecke, T. K., \& Thayer, J. F. (2014). Heart Rate Variability and Swimming. Sports Medicine. https://doi.org/10.1007/s40279-014-0211-9

Lai, E. R. (2011). Motivation: A Literature Review Research. Research Reports. https://doi.org/10.2307/3069464

Lazar, J. M., Khanna, N., Chesler, R., \& Salciccioli, L. (2013). Swimming and the heart. International Journal of Cardiology. https://doi.org/10.1016/j.ijcard.2013.03.063

Maass, C. C., Krüger, C., Herminghaus, S., \& Bahr, C. (2016). Swimming Droplets. Annual Review of Condensed Matter Physics. https://doi.org/10.1146/annurev-conmatphys-031115-011517

Manshuralhudlori. (2019). Kontribusi Panjang Tungkai, Kekuatan Otot Tungkai, Rentang Lengan Dan Volume Oksigen Maksimal Pada Prestasi Renang Gaya Crawl 100 meter. Jurnal Ilmiah Penjas, 5(1).

McFeeters, S. K. (2013). Using the normalized difference water index (ndwi) within a geographic information system to detect swimming pools for mosquito abatement: A practical approach. Remote Sensing. https://doi.org/10.3390/rs5073544

Mulyana, B. (2013). Hubungan Konsep Diri, Komitmen, dan Motivasi Berprestasi dengan Prestasi Renang Gaya Bebas. Jurnal Cakrawala Pendidikan, 3(3).

Mulyawati, C., Marijo, M., \& Indraswari, D. A. (2018). Mulyawati, C., Marijo, M., \& Indraswari, D. A. (2018). Korelasi antara Panjang Lengan dan Tungkai dengan Kecepatan Renang Gaya Bebas 50 meter (Studi pada klub renang SPECTRUM Semarang). Doctoral Dissertation, Faculty Of Medicine, (9). https://doi.org/10.1017/CBO9781107415324.004

Neiva, H. P., Marques, M. C., Barbosa, T. M., Izquierdo, M., \& Marinho, D. A. (2014). Warm-up and performance in competitive swimming. Sports Medicine. https://doi.org/10.1007/s40279-013-0117-y

Pelletier, L. G., Tuson, K. M., Fortier, M. S., Vallerand, R. J., Briére, N. M., \& Blais, M. R. (2016). Toward a New Measure of Intrinsic Motivation, Extrinsic Motivation, and Amotivation in Sports: The Sport Motivation Scale (SMS). Journal of Sport and Exercise Psychology. https://doi.org/10.1123/jsep.17.1.35

Peyer, K. E., Zhang, L., \& Nelson, B. J. (2013). Bio-inspired magnetic swimming microrobots for biomedical applications. Nanoscale. https://doi.org/10.1039/c2nr32554c

Purwanto. (2019). Hubungan Pengetahuan Ilmu Faal Olahraga Dengan Motivasi Berprestasi Pada Guru SD Penjasorkes Se-Kabupaten Lampung Barat. Universitas Lampung, Lampung.

Rahayu, E., \& Mulyana, O. P. (2015). Hubungan antara Goal-Setting dan Motivasi Berprestasi dengan Prestasi Atlet Renang. Character: Jurnal Penelitian Psikologi., 3(2), 1-5.

Rasyid, H. Al, Setyakarnawijaya, Y., \& Marani, I. N. (2017). Hubungan Kekuatan Otot Tungkai Dan Kekuatan Otot Lengan Dengan Hasil Renang Gaya Bebas 50 Meter Pada Atlet Millennium Aquatic Swimming Club. Jurnal IImiah Sport Coaching and Education, 1(1), 71-85. https://doi.org/10.21009/jsce.01106

Reiss, S. (2012). Intrinsic and Extrinsic Motivation. Teaching of Psychology. https://doi.org/10.1177/0098628312437704

Riswanto, H. A. (2017). Pengaruh Kekuatan Lengan, Kekuatan Tungkai Dan Motivasi Terhadap Kemampuan Renang Gaya Bebas Pada Perkumpulan Renang Kota Makassar. Doctoral Dissertation, Pascasarjana.

Robertson, S., Benardot, D., \& Mountjoy, M. (2014). Nutritional recommendations for synchronized swimming. International Journal of Sport Nutrition and Exercise Metabolism. https://doi.org/10.1123/ijsnem.2014- 
Rochmatullah, M. C. (2017). Hubungan Antara Kekuatan Otot Lengan, Kekuatan Otot Perut, Dan Kekuatan Otot Tungkai Terhadap KecepatanBerenang 50 Meter Gaya Bebas. (Studi Pada Atlet Putri Indonesia Muda Gresik). Jurnal Prestasi Olahraga, 1(1).

Rusli, H. (2017). Pengaruh Kekuatan Lengan, Kekuatan Tungkai Renang Gaya Dada Pada Atlit Putra Kota Makassar.

Santoso, D. S. (2016). Studi Korelasi Antara Kekuatan Otot Lengan Terhadap Prestasi Renang Gaya Bebas 50 Meter Pada Siswa Putra SMK PGRI 4 Kediri Tahun 2015. 1-13.

Schoenfeld, B. J. (2012). Does exercise-induced muscle damage play a role in skeletal muscle hypertrophy? Journal of Strength and Conditioning Research. https://doi.org/10.1519/JSC.0b013e31824f207e

Shaw, G., Boyd, K. T., Burke, L. M., \& Koivisto, A. (2014). Nutrition for swimming. International Journal of Sport Nutrition and Exercise Metabolism. https://doi.org/10.1123/ijsnem.2014-0015

Stoyanov, S. (2017). A theory of human motivation. In A Theory of Human Motivation. https://doi.org/10.4324/9781912282517

Sudarsono, S. (2015). Penyusunan Program Pelatihan Berbeban Untuk Meningkatkan Kekuatan. IImiah Spirit, 12(1), 31-43.

Sukmawati, D. (2015). Penerapan Pemebelajaran Renang Gaya Bebas Terhadap Hasil Belajar Renang Gaya Bebas. Jurnal Pendidikan Olahraga Dan Kesehatan, 03(2), 366-370.

Surahman, F. (2016). Pengaruh Metode Repetisi Dan Metode Interval Intensif Terhadap Kecepatan Renang Gaya Bebas 50 Meter. Curricula, 2(2), 31-40. https://doi.org/10.22216/jcc.2016.3140

Tierney, K. B. (2011). Swimming performance assessment in fishes. Journal of Visualized Experiments. https://doi.org/10.3791/2572

Tight, M., Symonds, P., \& Symonds, P. M. (2016). The Case Study as a Research Method. In Case Studies. https://doi.org/10.4135/9781473915480.n2 